\title{
The Relationship between Academic Dishonesty, Ethical Attitude and Ethical Climate: The Evidence from Taiwan
}

\author{
Yao-Chung Cheng ${ }^{1, *(\mathbb{D}, \text { Fang-Chih Hung }}{ }^{2}$ and Hung-Ming $\mathrm{Hsu}^{3}$ \\ 1 Center for Teacher Education, National Changhua University of Education, Changhua 50007, Taiwan \\ 2 National Caotun Commercial \& Industrial Vocational Senior High School, Nantou 54253, Taiwan; \\ fchong@mail.ttvs.ntct.edu.tw \\ 3 National Hsin Hua Senior High School, Tainan 71251, Taiwan; shm@mail.ttvs.ntct.edu.tw \\ * Correspondence: yaochung@cc.ncue.edu.tw; Tel.: +886-7232105 (ext. 1127)
}

Citation: Cheng, Y.-C.; Hung, F.-C.; Hsu, H.-M. The Relationship between Academic Dishonesty, Ethical Attitude and Ethical Climate: The Evidence from Taiwan. Sustainability 2021, 13, 11615. https://doi.org/ $10.3390 /$ su132111615

\section{Academic Editors: Eloy}

López Meneses, Emilio José Delgado-Algarra,

César Bernal-Bravo and Antonio

Alejandro Lorca-Marín

Received: 23 September 2021

Accepted: 17 October 2021

Published: 21 October 2021

Publisher's Note: MDPI stays neutral with regard to jurisdictional claims in published maps and institutional affiliations.

Copyright: (c) 2021 by the authors. Licensee MDPI, Basel, Switzerland. This article is an open access article distributed under the terms and conditions of the Creative Commons Attribution (CC BY) license (https:/ / creativecommons.org/licenses/by/ $4.0 /)$.

\begin{abstract}
Academic dishonesty has become a global issue widely studied in many countries. Plagiarism using the Internet is prevalent across the world and seems to be increasing, affecting the reputation of schools and even countries. On the basis of the social cognitive theory and the theory of planned behavior, this study explored the relationship between ethical attitude and academic dishonesty, and we focused on the moderating effect of ethical climate on the relationship. A survey of 1271 students (745 female students, 526 male students; mean age $=16.38$ years, $\mathrm{SD}=0.76$ ) from 31 senior high schools in Taiwan was conducted and analyzed using hierarchical regression by SPSS 26 to test the hypotheses of this study. The result shows that: (1) Compared with male students, female students had a more positive attitude towards ethical attitude and showed less academic dishonesty. Compared with general senior high school students, vocational senior high school students showed a more positive ethical attitude and a positive ethical climate; (2) ethical attitude was negatively related to academic dishonesty; (3) high ethical climate strengthened the negative relationship between ethical attitude and academic dishonesty. In addition, the theoretical implications, practical implications, and directions for future research are also discussed in this article. The result of the study can be a credible reference for educational researchers and educational administrative systems, when planning ethical-related courses or educational policies for high schools with more emphasis on academic dishonesty and other relevant issues.
\end{abstract}

Keywords: ethical attitude; academic dishonesty; ethical climate

\section{Introduction}

Academic dishonesty has become a global issue widely studied in many countries, such as the United States, Canada, United Kingdom, Sweden, Germany, Romania, Greece, Pakistan, East Africa, South Africa, Russia, New Zealand, China, Australia, Malaysia, Japan, and Taiwan [1-8]. To illustrate, Sisti [4] investigated the perspective of high-school students on internet plagiarism and found that approximately $35 \%$ of the students had an experience of copy-pasting texts or ideas from others as their own without crediting the original source. Other researchers such as Thomas [6], Finchilescu and Cooper [1], and Tatum et al. [9] directed their focus on college students and found that $50 \%, 63 \%$, and $74 \%$ of the students admitted to some form of academic dishonesty. Radulovic [3] cited statistical data from other research studies showing that more than $90 \%$ of college students in the United States have committed acts of academic dishonesty. Recent studies have revealed that a high percentage of academic dishonesty was found in college students within the Chinese context [10-13]. This indicates that this behavior is prevalent across the world and seems to be increasing [5]. Additionally, researchers commented that academic dishonesty could have a severe impact on a school's reputation. These students are likely to become an employee or a leader with academic dishonesty in a future workplace $[1,2,5]$. As such, academic honesty is valued by both academia and industry greatly. 
Academic dishonesty is the act of cheating during exams or plagiarizing research or reports from other people to gain unlawful benefits [6]. In academia, it also means any unethical behaviors that violate the code of conduct for research integrity, such as plagiarizing, fraudulence, buying others' research papers as ones' own, citing incorrect sources, delinquency, unauthorized help, manipulating academic staff, falsifying data, or cheating during an exam and getting others to take examinations [5,14,15]. According to Karim, Zamzuri, and Nor [16], we defined academic dishonesty as unethical behaviors that refer to fraudulence, plagiarism, falsification, and internet misuse. Prior research on independent variables about academic dishonesty includes individual variables: demographic (such as genders or ages), individual differences (such as personal traits, internal and external locus of control, or mindsets), attitudes, academic performance, ethical values, majors, external motivation; organizational variables: social values and norms, organizational punishment policies regarding academic dishonesty, attitudes toward peers and perceptions of behaviors, contextual factors (such as campus or learning climate), traditional honor code, and the scale of schools, student-to-faculty ratio; and national-level variables: student educational stages (such as a comparison between college students and high school students), and national culture (individualism or collectivism) $[1,6,9,17]$. Research in these areas has identified that among these independent variables, attitude is the most influential one $[8,18]$.

A majority of participants in the aforementioned studies were college students (yet, the 2014 research of Muñoz-García and Aviles-Herrera focused on the difference between dishonest college and high school students), whereas studies on attitudes and behaviors of high school students toward academic ethics are relatively rare [4]. The curriculum guidelines for 12-year basic education in Taiwan (hereinafter referred to as "new curriculum guidelines"; Ministry of Education [19]) were released by the MOE of Taiwan in 2014 and later went into effect in 2019. The new curriculum guidelines requested all high schools in Taiwan to incorporate inquiry and practice-based courses in natural science and social science into the MOE-mandated curricula. In addition, schools should plan and include integrated theme-, project-, or cross-disciplinary/domain-specific, and practice (experiments) courses in their school-based courses according to the characteristics of each school. Students who take these courses may participate in course-related competitions (such as national short essay contests, project competitions, or science fairs) with their term projects, so it is clear that the implementation of new curriculum guidelines can generate more and more opportunities for students to conduct academic-related research and publication in either curriculum or competition context. However, courses concerning a wide range of issues that high school students should learn have never been established.

Since ethical justice forces people to have ethical obligations and responsibilities, individuals with positive ethical attitudes may show less tendency to academic dishonesty. Rare research explores the relationship between ethical climate, ethical attitude, and academic dishonesty. Therefore, it is believed that this research can fill the gap in theory and enhance the researchers' understanding of academic dishonesty. In this study, we tried to answer the following questions: (a) Does the score of high school students' ethical climate, ethical attitudes, and academic dishonesty reveal significant differences according to gender, school types, and whether to take project-based practical courses? (b) What is the relationship between ethical attitude and academic dishonesty? (c) How the contextual variable, ethical climate, moderates the negative relationship between high school students' ethical attitude and academic dishonesty.

\section{Literature Review and Research Hypothesis}

\subsection{Theoretical Background}

Based on the theory of planned behavior (TPB) [20], this study explored the relationship between high school students' ethical attitudes and academic dishonesty. Putting social cognitive theory (SCT) in perspective, personal behaviors never exist independently and fixed but are the outcome of individuals' continuous interaction with their social 
environments [21]. Bandura argued that the individual influence includes personality traits, cognitive, and other factors. The behavioral influence includes the individual's specific behaviors, while the environmental influence includes social norms, rules and regulations, and encouragement from peers. These three influences are correlated to one another as personal behaviors are shaped by personal factors interacting with external environments, an interaction that will have an impact on personal behaviors according to different contexts.

Prior studies have shown that a positive ethical climate will create a context that can inspire organization members to behave ethically. This finding exemplifies the importance of how students respond to their classmates' academic dishonesty and is affected by peer reactions. It illustrates the prominent role that the teacher plays in project-based practical courses in conveying students with ethical attitudes as well. Given this perspective, this study explored whether this variable, the ethical climate (the interaction between individuals, peers, and teachers), could moderate the relationship between high school students' ethical attitudes and academic dishonesty. Figure 1 depicts the theoretical model of our study, and each path of this model is explained below.

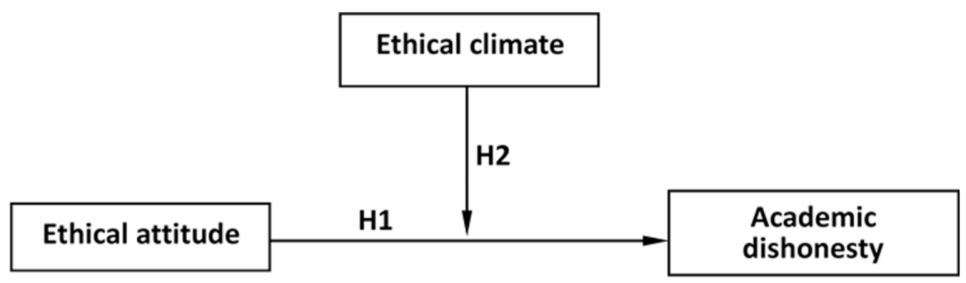

Figure 1. Theoretical Model.

\subsection{Research Hypotheses}

2.2.1. The Relationship between Ethical Attitude and Academic Dishonesty

Zopiatis and Krambia-Kapardis [22] argued that ethics help one to decide what is right, fair, just, or good, i.e., what one ought to do, not just what is the case or what is most acceptable. Academic ethics refers to the moral principles and standards that guide behavior in academic settings. Following Zopiatis and Krambia-Kapardis's [22] definition, we defined ethical attitude as the students' ethical judgement towards violation of school regulations, selfishness, academic cheating, and computer ethics.

Ajzen [20] proposed the TPB to comprehend and predict personal behaviors. The theory argued that attitude toward behaviors, subjective norms, and perceived behavioral control could affect their behavioral intentions and then regulated their actual behaviors. Attitude is a positive or negative opinion that a person holds to another one, thing, or behavior, including "good-bad", "pleasant-unpleasant", "harmful-beneficial", and other feelings [23]. The more positive a person felt toward a behavior, the stronger their behavioral intentions would be. Subjective norms are the social pressure a person feels when taking a certain action. This is the perception of social pressure from other people or groups (such as teachers, friends, peers, and so on) on a person to take action. The stronger the positive subjective norms became, the easier the climate to take the preferred action. Perceived behavioral control is the perception of a person's control power on needed resources and opportunities when engaging in certain behavior. The more intense a person perceived their control power on resources and opportunities, the higher the intention to support that behavior became. Similarly, if a person held a more positive attitude to certain behaviors, more supportive subjective norms, and stronger perceived behavior control, the intention to undertake certain behaviors would be stronger. Among these three factors, the attitude was the most influential one in terms of behavioral intentions $[8,18]$.

That is the reason that while high school students are studying at school, they can participate in many research courses or competitions, such as "topical studies", "science fairs", "project-based practical courses", or "national short essay contests". A positive ethical attitude can generate positive behavioral intention (behavioral determinant), leading 
a person toward positive actual behaviors with a lower rate of academic dishonesty, and vice versa.

On the same level, empirical studies similar to this study had revealed that higher moral standards would prompt students to be more academically honest [24]. In addition, a great number of scholars had found that positive moral belief and attitude could significantly reduce cheating behaviors in the academic context [25-28]. Equally, Chen et al. [29] conducted an experiment on students at vocational schools and saw information ethical attitude was negatively related to academically unethical behaviors. Yu, Glanzer, and Johnson [30] found that attitude toward academic misconduct relates to college student engagement in academic cheating. Zhang, Yin, and Zheng [8] showed that moral attitude and integrity engagement are the major predictors of academic dishonesty. The findings from Chiang and Lee [31] showed that attitude has a positive impact on the personal observation of information ethics.

It is clear that a positive ethical attitude can reduce academic dishonesty and so our research hypothesis was proposed as below.

\section{Hypothesis 1 (H1). Ethical attitude is negatively related to academic dishonesty.}

\subsubsection{The Moderating Effect of Ethical Climate}

In light of the TPB [20], attitude mattered, but two other determinants could also spur personal behaviors. These were subjective norms and perceived behavioral control. Social pressure from either peers or teachers, as an example, illustrated the subjective norms to trigger certain behaviors or not; perceived behavioral control is any possible penalty that behavior will elicit. This study adopted Schwepker Jr's scale [32] with test items that already covered the subjective norms of peers and teachers upon academic ethical behaviors with a wide range of penalty severity in response to academic dishonesty.

In the SCT, Bandura [21] argued that cognition is mutually correlated with personal, behavioral, and environmental influences. The personal influences included personality traits, cognitive, or other factors. The behavioral influences included the individual's specific behaviors. The environmental influences included social norms, rules, and regulations, as well as encouragement from peers. Bandura explored human behaviors from the perspective of "triadic reciprocal causation", where personal behaviors were shaped by individual influence interacting with external environments. This was an interaction that would have an impact upon personal behaviors according to different contexts. This was a widely applied theory in various education research areas. In recent years, an increasing number of scholars applied it to study ethical attitudes or behaviors [33,34]. Consequently, based on Bandura's SCT, this study explored the moderating effect of ethical climate on the negative relationship between ethical attitude and academic dishonesty.

In addition, Ferrell and Gresham [35] found that when an organization lacked ethical rules and regulations or instructions to explain, prohibit, supervise, and correct unethical behaviors, this would create a climate of unethical behaviors. In the study by Victor and Cullen [36], they pointed out that ethical climate was the organizational members' shared perception of the ethical values that drove the organization's practices and procedures. Schwepker Jr [32] further explained that ethical climate meant how organizational members commonly perceived any ethics-related rules or regulations, and top managerial action. The importance of creating academic ethical climates through policies or regulations of a school to curb academic dishonesty had been recognized by some scholars [37]. Therefore, ethical climates would affect many policies in an organization, and so top managers played an instrumental role in maintaining and creating an organizational ethical climate [9].

In the new curriculum guidelines for high schools in Taiwan, "project-based practical courses" are one of the school-developed required curricula, but practice-based courses such as "topical studies", "science fairs", "project-based practical courses", "national short essay contests", and codes or regulations of the school, rarely highlight relevant academic ethical issues [19] to guide students to behave ethically. As a result, ethics-related require- 
ments come mainly from teachers or competition advisors during lecturing or gaming. Students may also be disciplined by educators with similar codes or regulations or by peers. Accordingly, based on the perspectives from Schwepker Jr [32], this study defined ethical climates as a perception of ethics-related issues formed during participation in "topical studies courses" or "project-based practical courses", "science fairs", or "national short essay contests" by students responding to any codes, regulations, disciplines from teachers, competition advisors, or peers. In light of the findings by Schein [38] and Schwepker Jr [32], it was understood that regulations from high school educators and peers were the key to maintaining and creating an ethical climate on the school campus. This perspective was aligned with Simkin and McLeod [28] as they argued that both peers (such as classmates and friends) and important authorities (such as teachers) were essential in creating a climate to curb academic dishonesty.

According to SCT, when students perceived their surrounding climates as highly ethical, they might notice the strong commitment or regulations on academic ethics by their teachers (or competition advisors), as well as encouragement from peers or peer norms. That commitment and those regulations served as directive feedback to students for self-regulation and self-reflection [21], which in turn guided individuals' behaviors. The students could accordingly align their own behaviors with academic ethics. This would strengthen the negative relationship between ethical attitude and academic dishonesty. Similarly, Ajzen [20] proposed that a context that was created by a high ethical climate would initiate subjective norms on a person, which could make she/he feel social pressure when taking certain actions. In other words, teachers (or competition advisors) or classmates of a person could stress to him or her to hesitate about their academic dishonesty. The stronger the positive subjective norms, the less likely students will be dishonest academically.

In regard to previous empirical studies similar to this study, the findings by McCabe and Treviño [39] saw that academic dishonesty was significantly related to either honor codes in an organization or cheating among peers. McCabe [40] also found that the most effective measure to curb academic dishonesty was to educate students about the importance of ethical academic behaviors. It was clear that both peers (classmates and friends) and ethical academic codes were essential in creating a climate to restrain academic dishonesty [39,40]. Birtch and Chiang [41] argued that students with positive perceptions about their business school's ethical climate were more likely to refrain from unethical behaviors.

Together, we suggested that a high ethical climate may strengthen the negative relationship between ethical attitude and academic dishonesty. Therefore:

Hypothesis 2 (H2). Ethical climate will moderate the negative relationship between ethical attitude and academic dishonesty. The relationship may become more negative in a high ethical climate.

\section{Method}

\subsection{Participants and Procedure}

The population of this study was 1271 students (745 female students, 526 male students; mean age $=16.38$ years, $S D=0.76$ ) from Taiwan's 2020 senior high schools, including 583 general senior high schools, and 688 vocational senior high schools and comprehensive senior high schools. We used stratified sampling, selecting 17 general senior high schools, and 14 vocational senior high schools and comprehensive senior high schools. The researcher personally called the school principal or the dean of academic affairs to explain in detail the purpose of the research and the method of answering the questions, and then sent questionnaire packages to them after obtaining their consent.

Before administering the questionnaire, the researcher explained in detail the purpose and content of the research to the principals or directors of all high schools. After their discussion, they agreed to administer the questionnaire at their school. The teachers of each high school conducted the survey and informed the participants of the confidentiality of the information collected and the principle of voluntary participation. This study 
obtained the informed consent of the participants and their teachers. Before completing the questionnaire, all participants not only obtained oral and written information on how to fill out the anonymous questionnaire, but were also promised that the answers to this survey were not related to their school achievements. Participants could feel safe when answering the questionnaire and improve the accuracy of the data.

Regarding the research sample, a majority of participants $(72.5 \%)$ were studying at national high schools, $24.2 \%$ at municipal, and only $3.1 \%$ at other public schools. Just over half $(51.6 \%)$ came from the ninth grade, close to half $(43.8 \%)$ from the eighth grade, and only $4.6 \%$ from the seventh grade. Overall, $58.5 \%$ were female and $41.5 \%$ were male. Of the school types, $45.9 \%$ were general senior high school, and $54.1 \%$ were vocational senior high schools and comprehensive senior high schools. In addition to the question concerning their previous basic academic research or school competitions, project-based practical courses accounted for $55.1 \%$, national short essay contests for $58.1 \%$, topical studies for $41.7 \%$, and science fairs for $20.4 \%$. Around half of the participants had joined basic academic research or competitions. In terms of the popularity of technological products, $99 \%$ of the participants responded that they had desktops or other mobile devices (such as laptops, tablets, or smartphones) at home. Over $97 \%$ of the students had access to the internet at home. When asked about their technological experiences, nine years and above made up $39.7 \%$, six to nine years $30.7 \%$, three to six years $20.1 \%$, and less than three years $9.5 \%$. This background survey presented that approximately $90 \%$ of the participants had used computers for more than three years.

\subsection{Measures}

\subsubsection{Description for Instruments}

Three statement scales developed by foreign scholars were utilized in this study and rendered by different translators into Chinese in light of the back-translation method proposed by Brislin [42]. Furthermore, four senior high school principals with a doctoral degree were invited to evaluate the propriety of the survey so that both the scale face validity and equivalence between the Chinese version and the English version were acceptable. This is elaborated below.

\section{- $\quad$ Ethical attitude}

The ethical attitude was measured with a 19-item statement scale developed by Zopiatis and Krambia-Kapardis [22] that contained four dimensions to assess: violation of school regulations (four items) with test items such as "Use another student's computer account without his/her permission"; selfishness (six items) with test items such as "Use a bribe in order to secure preferential treatment crucial to your professional development during your studies"; academic cheating (five items) with test items such as "Submit the same paper (with cosmetic changes) to more than one class"; and computer ethics (four items) with test items such as "Duplicate a copyrighted e-book without permission". A fivepoint Likert scale ranging from (1) strongly agree to (5) strongly disagree was administered to measure the participant's opinions on ethical attitude. Higher points indicated a higher degree of agreement with the ethical attitude. The Cronbach's Alpha of the original scale was 0.89 .

\section{- Academic dishonesty}

The academic dishonesty was measured with a 26-item statement scale developed by Karim and Zamzuri [16] with four dimensions assessing: fraudulence (10 items) with test items such as "Sabotaging other people's academic work through the Internet"; plagiarism (5 items) with test items such as "Using other people's complete works on the Internet for personal assignments without acknowledging the author"; falsification ( 3 items) with test items such as "Paraphrasing the internet resource in a way that deteriorates the integrity of the original idea"; and misuse (8 items) with test items such as "Reading e-mail during lectures/in classroom". All participants were asked to answer the frequency of their academic dishonesty on a five-point Likert scale (never $=1$, always $=5$ ). Higher points 
indicated a higher frequency of academic dishonesty. The Cronbach's Alpha of the original scale was 0.83 .

\section{- $\quad$ Ethical climate}

The ethical climate was measured with a seven-item statement scale developed by Schwepker Jr [32] and a five-point Likert scale (strongly disagree $=1$, strongly agree $=5$ ) was used for the assessment. Test items included "My teacher has a formal, written code of ethics" and "Top management in my school has let it be known in no uncertain terms that unethical behaviors will not be tolerated". Higher points indicated a stronger personal perception of the ethical climate. The Cronbach's Alpha of the original scale was 0.89.

- Control variables

Prior studies showed that some demographic variables were significantly correlated to academic dishonesty [8], so in this study, the grade, gender, participation in project-based practical courses, and computers or technological devices at home were to be controlled as these four were significantly correlated to academic dishonesty.

\subsubsection{Confirmatory Factor Analysis for Instruments}

In order to verify the reliability and validity of the research tool, we took 1271 Taiwanese senior high school students as a sample and performed a confirmatory factor analysis of three scales. The results are shown in Table 1. The ethical attitude scale showed fit indices- $\chi^{2}(148, \mathrm{~N}=1271)=1449.15, \mathrm{NNFI}=0.96, \mathrm{CFI}=0.96, \mathrm{SRMR}=0.05$, and RMSEA $=0.08$. The academic dishonesty scale showed fit indices- $\chi^{2}(295, N=1271)=$ 2470.26, NNFI $=0.96, \mathrm{CFI}=0.96, \mathrm{SRMR}=0.07$, and RMSEA $=0.07$. The ethical climate showed fit indices- $\chi^{2}(11, \mathrm{~N}=1271)=74.20, \mathrm{NNFI}=0.98, \mathrm{CFI}=0.99, \mathrm{SRMR}=0.03$, and RMSEA $=0.07$. Regarding the scale of ethical climate, however, for two reasons, we let the error terms on item 1 and item 2, item 3 and item 4 , as well as item 6 and item 7 be correlated during the analysis, respectively. First, the original items' wording was really similar. For instance, item 1 was "My school has a formal, written code of ethics", and item 2 was "My school enforces a code of ethics". Second, the Pearson's correlation coefficients of item 1 and item 2, item 3 and item 4 , as well as item 6 and item 7 , were $0.80,0.80$, and 0.87 . These coefficients showed high a correlation between the pairs of items, respectively. NNFI and CFI were greater than or equal to 0.9 [43,44], RMSEA value less than 0.05 indicates a good model fit [44], and SRMR less than 0.08 indicates a fair level of fit between data [44].

Table 1 shows that the factor loadings of each scale were between 0.40 and 0.88 and greater than the standard of 0.40 [45], and the Cronbach's $\alpha$ values of all scales and subscales were higher than the required level of 0.7 [46], indicating that there was acceptable internal reliability between the constructs. The construct reliabilities (CR) were greater than 0.7 , and the average variance extracted (AVE) of each construct was greater than the 0.30 acceptable standard [43,47]. The above results indicate that the constructs of the measurement had acceptable reliability, validity, and model fitness. 
Table 1. Results of confirmatory factor analysis for scales.

\begin{tabular}{|c|c|c|c|c|c|c|}
\hline Scales & Dimensions & $\begin{array}{c}\text { Factor } \\
\text { Loadings }\end{array}$ & $\alpha$ & CR & AVE & Fit Indices \\
\hline \multirow{3}{*}{ Ethical attitude } & $\begin{array}{l}\text { Violation of school } \\
\text { regulations }\end{array}$ & $0.57-0.69$ & 0.73 & 0.73 & 0.41 & \multirow{3}{*}{$\begin{array}{l}\chi^{2}=1449.15 \\
d f=148 \\
\text { RMSEA }=0.08 \\
\text { SRMR }=0.05 \\
\text { NNFI }=0.96 \\
\text { CFI }=0.96 \\
\text { Overall } \alpha=0.91\end{array}$} \\
\hline & Selfishness & $0.51-0.73$ & 0.79 & 0.78 & 0.37 & \\
\hline & $\begin{array}{l}\text { Academic cheating } \\
\text { Computer ethics }\end{array}$ & $\begin{array}{l}0.68-0.85 \\
0.40-0.86\end{array}$ & $\begin{array}{l}0.86 \\
0.76\end{array}$ & $\begin{array}{l}0.58 \\
0.50\end{array}$ & $\begin{array}{l}0.58 \\
0.50\end{array}$ & \\
\hline \multirow{4}{*}{$\begin{array}{l}\text { Academic } \\
\text { dishonesty }\end{array}$} & Fraudulence & $0.50-0.77$ & 0.87 & 0.87 & 0.42 & \multirow{4}{*}{$\begin{array}{l}\chi^{2}=2470.26 \\
d f=295 \\
\text { RMSEA }=0.07 \\
\text { SRMR }=0.07 \\
\text { NNFI }=0.96 \\
\text { CFI }=96 \\
\text { Overall } \alpha=0.92\end{array}$} \\
\hline & Plagiarism & $0.64-0.88$ & 0.84 & 0.86 & 0.54 & \\
\hline & Falsification & $0.63-0.80$ & 0.75 & 0.77 & 0.53 & \\
\hline & Misuse & $0.56-0.85$ & 0.91 & 0.91 & 0.56 & \\
\hline Ethical climate & & $0.50-0.78$ & 0.88 & 0.86 & 0.47 & $\begin{array}{l}\chi^{2}=74.20 \\
d f=11 \\
\text { RMSEA }=0.07 \\
\text { SRMR }=0.03 \\
\text { NNFI }=0.98 \\
\text { CFI }=0.99\end{array}$ \\
\hline
\end{tabular}

Note: $\alpha=$ Cronbach's alpha; $\mathrm{CR}=$ composite reliability; $\mathrm{AVE}=$ average variance extracted.

\subsection{Analytical Strategy}

The collected data were analyzed by the Statistical Package for Social Science (SPSS) 26.0 , using hierarchical regression to examine the proposed hypotheses and two hierarchy regressions to analyze the moderating effect of ethical climate on the negative relationship between ethical attitude and academic dishonesty. Prior to the analysis, both the independent variable and moderator were mean-centered to avoid the regression model inhabiting multi-collinearity diagnosis. Based on the variance inflation factor (VIF) which was proposed by Kutner et al. [48], set to be less than 10 as the benchmark, the VIF value in this study was scored between 1.006 and 1.135, indicating a weak multi-collinearity diagnosis influence on the study result. As a result, the regression procedure followed this sequence: (1) add control variables; (2) add two main effects of variables (ethical attitude and ethical climate); (3) add the interaction term of ethical attitude and ethical climate.

\section{Results}

\subsection{Test the Extent of the Common Method Variance (CMV)}

The data were self-reported, which required the measurement of common method biases. The common method variance was (CMV) due to the independent variable data (ethical attitude), dependent variable data (academic dishonesty), and moderator (ethical climate) all originating from the same respondents. This situation may have caused a CMV issue and overestimation of the relationship between variables [49,50]. Therefore, we used methodological measurement separation to design the questionnaire to tackle the potential CMV issue, namely, simplifying intricate, nebulous, statement-based measurement items and replacing the original titles of each scale on the questionnaire with "the first section," "the second section," and "the third section." Sensitive descriptions or explanations were also avoided to minimize the odds of students' having misleading social desirability [51]. The anonymous questionnaire upon completion was collected by the contact window of each high school and sent back directly to the researcher for analysis without teachers' 
interference. Furthermore, we used the Herman single factor test to analyze the possible issue of CMV in the study [52]. Exploratory factor analysis was conducted on all of the 52 items in the questionnaire. The results show that nine factors had Eigen values greater than 1 . The nine factors accounted for $63.98 \%$ of the total variance, and the first factor only for $28.28 \%$, which is far less than $40 \%$, a cutoff value dividing large or small CMV [53]. It can be said that common method bias was not a problem in this study. In these ways, these CMV and social desirability concerns were unlikely to have had significant or adverse effects on our results.

\subsection{Descriptive Statistics, Coefficients, and Reliability}

Table 2 lists the descriptive statistics, coefficients, and reliability values for all variables in the study. The findings show that ethical attitude was not only significantly negatively correlated with academic dishonesty $(\mathrm{r}=-0.48, p<0.01)$ but also significantly positively correlated with ethical climate $(\mathrm{r}=0.18, p<0.01)$. Ethical climate was significantly negatively correlated with academic dishonesty $(\mathrm{r}=-0.06, p<0.05)$.

Table 2. Descriptive statistics, reliabilities, and correlations.

\begin{tabular}{|c|c|c|c|c|c|c|c|c|c|}
\hline Variable & Mean & $S D$ & 1 & 2 & 3 & 4 & 5 & 6 & 7 \\
\hline 1. Grade & NA & NA & - & & & & & & \\
\hline 2. Gender & 0.41 & 0.49 & $-0.10^{* *}$ & - & & & & & \\
\hline 3. $\mathrm{PB}$ & 0.55 & 0.50 & $0.25^{* *}$ & 0.03 & - & & & & \\
\hline $\begin{array}{l}\text { 4. Notebook/Tablet } \\
\text { PCs at home }\end{array}$ & 0.99 & 0.10 & -0.05 & -0.03 & 0.03 & - & & & \\
\hline 5. EA & 4.31 & 0.51 & $0.07 *$ & $-0.24 * *$ & -0.02 & $0.05^{+}$ & $(0.92)$ & & \\
\hline 6. EC & 3.61 & 0.76 & 0.02 & -0.01 & 0.03 & -0.01 & $0.18^{* *}$ & $(0.88)$ & \\
\hline 7. $\mathrm{AD}$ & 1.60 & 0.49 & $0.08 * *$ & $0.13^{* *}$ & $0.10 * *$ & $-0.05^{+}$ & $-0.48^{* *}$ & $-0.06^{*}$ & $(0.93)$ \\
\hline
\end{tabular}

Note 1: ${ }^{* *} p<0.01, * p<0.05,+p<0.10$, the value in parentheses is the reliability value; $\mathrm{n}=1271$. Note 2: the grade (3: third grade; 2 : second grade; 1: first grade), gender (0: female; 1 : male), PB: project-based practical course (0: no; 1 : yes), PC/technological devices at home (0: no; 1: yes) are control variables. Note 3: $\mathrm{EA}=$ ethical attitude, $\mathrm{EC}=$ ethical climate, $\mathrm{AD}=$ academic dishonesty, $\mathrm{PB}=$ project-based practical course.

\subsection{Gender, School Types, and Project-Based Practical Course Comparisons on the Scales}

Table 3 shows gender, school types, and PB t-tests comparisons on our three variables. First, Table 3 reveals that, on the ethical attitude, male students expressed statistically more negative attitudes than female students did $(t=-8.97, p<0.001)$. Furthermore, on academic dishonesty, male students expressed more academic dishonesty behavior than female students did $(t=-4.48, p<0.001)$. However, the difference between male and female students' scores on the ethical climate was insignificant.

Second, Table 3 reveals that, on the ethical attitude, vocational senior high school students expressed statistically more positive ethical attitudes than general senior high school students did $(t=-4.663, p<0.001)$. Furthermore, on the ethical climate, vocational senior high school students felt more positive ethical climate than general senior high school students felt $(t=-5.213, p<0.001)$. However, the difference between general senior high school and vocational senior high school students' scores on academic dishonesty was insignificant.

Finally, Table 3 shows that, on academic dishonesty, students who took the projectbased practical course expressed more academic dishonesty behaviors than those who did not take the project-based practical course $(t=3.725, p<0.001)$. However, the scores on the ethical attitude and ethical climate did not show statistical differences for students who took the project-based practical course and those who did not. 
Table 3. t-tests for gender, school types, and PB differences of studied variables.

\begin{tabular}{|c|c|c|c|c|c|}
\hline Variables & Back & and & Mean & S.D. & $\mathbf{t}$ \\
\hline \multirow{2}{*}{ EA } & \multirow{6}{*}{ Gender } & Male & 78.96 & 11.10 & \multirow{2}{*}{$-8.970^{* * *}$} \\
\hline & & Female & 83.80 & 8.12 & \\
\hline \multirow{2}{*}{$\mathrm{AD}$} & & Male & 43.41 & 14.55 & \multirow{2}{*}{$4.480^{* * *}$} \\
\hline & & Female & 40.21 & 10.90 & \\
\hline \multirow{2}{*}{ EC } & & Male & 25.21 & 5.39 & \multirow[b]{2}{*}{-0.310} \\
\hline & & Female & 25.30 & 5.23 & \\
\hline \multirow{2}{*}{ EA } & \multirow{6}{*}{ School types } & GHS & 80.43 & 9.33 & \multirow{2}{*}{$-4.663^{* * *}$} \\
\hline & & VHS & 82.97 & 9.93 & \\
\hline \multirow{2}{*}{$\mathrm{AD}$} & & GHS & 41.07 & 11.22 & \multirow{2}{*}{-1.169} \\
\hline & & VHS & 41.90 & 13.70 & \\
\hline \multirow{2}{*}{ EC } & & GHS & 24.43 & 4.89 & \multirow{2}{*}{$-5.213^{* * *}$} \\
\hline & & VHS & 25.96 & 5.53 & \\
\hline \multirow{2}{*}{ EA } & \multirow{6}{*}{ PB } & PB & 81.60 & 10.17 & \multirow{2}{*}{-0.804} \\
\hline & & NON-PB & 82.05 & 9.22 & \\
\hline \multirow{2}{*}{$\mathrm{AD}$} & & PB & 42.71 & 13.40 & \multirow{2}{*}{$3.725 * * *$} \\
\hline & & NON-PB & 40.07 & 11.45 & \\
\hline \multirow{2}{*}{ EC } & & PB & 25.38 & 5.54 & \multirow{2}{*}{0.913} \\
\hline & & NON-PB & 25.11 & 4.99 & \\
\hline
\end{tabular}

Note 1: ${ }^{* * *} p<0.001$. Note 2: EA = ethical attitude, $\mathrm{AD}=$ academic dishonesty, $\mathrm{EC}=$ ethical climate. Note 3 GHS = general senior high school, VHS = vocational senior high school and comprehensive senior high school; $\mathrm{PB}=$ students who took the project-based practical course, $\mathrm{NON}-\mathrm{PB}=$ students who did not take the project-based practical course. Note 4: $n=1271$, Male $=526$, Female $=745 ; G H S=583, V H S=688 ; P B=700$, NON-PB $=571$.

\subsection{Hypotheses Test}

All collected data were analyzed with hierarchical regression to test the suggested hypotheses as in model 2 of Table 4 . The model showed that ethical attitude was in a significantly negative relationship with academic dishonesty $(\beta=-0.48, p<0.01)$ and suggested that a student with a more positive ethical attitude was less likely to be academically dishonest. Consequently, this result supported Hypothesis 1. In this model, the moderating effect of ethical climate was also tested. The main effect of ethical attitude was measured as statistically significant. The interactive term between the moderator and independent variable was added in model 3 of Table 4 , and the finding saw that the standardized regression coefficient was statistically significant $(\beta=-0.20, p<0.01)$, supporting Hypothesis 2 that a high ethical climate will strengthen the negative relationship between ethical attitude and academic dishonesty.

Table 4. Summary of academic dishonesty hierarchical regression.

\begin{tabular}{|c|c|c|c|}
\hline \multirow{2}{*}{ Predictors } & \multicolumn{3}{|c|}{ Academic Dishonesty } \\
\hline & Model 1 & Model 2 & Model 3 \\
\hline \multicolumn{4}{|l|}{ Step 1: Control variables } \\
\hline Grade & $0.08^{* *}$ & $0.10^{* *}$ & $0.10 * *$ \\
\hline Gender & $0.14^{* *}$ & 0.02 & 0.01 \\
\hline $\mathrm{PB}$ & $0.08^{* *}$ & $0.06^{*}$ & 0.06 * \\
\hline Home PC/tech devices & -0.05 & -0.02 & -0.02 \\
\hline \multicolumn{4}{|l|}{ Step 2: Main effect } \\
\hline EA & & $-0.48^{* *}$ & $-0.45^{* *}$ \\
\hline $\mathrm{EC}$ & & 0.02 & 0.03 \\
\hline \multicolumn{4}{|l|}{ Step 3: Moderating effect } \\
\hline $\mathrm{EA} \times \mathrm{EC}$ & & & $-0.20 * *$ \\
\hline$\Delta \mathrm{F}$ & $11.11^{* *}$ & $172.62 * *$ & $68.01 * *$ \\
\hline Adjusted $\mathrm{R}^{2}$ & 0.03 & 0.24 & 0.28 \\
\hline$\Delta \mathrm{R}^{2}$ & $0.03^{* *}$ & $0.21 * *$ & $0.04^{* *}$ \\
\hline
\end{tabular}


As further understanding was needed on the moderating effect of ethical climate on the relationship between ethical attitude and academic dishonesty, this study adopted the method suggested by Aiken and West [54] to map the interaction effect as shown in Figure 2, which illustrates that low ethical climate could incubate a higher frequency of student academic dishonesty in contrast to the high ethical climate. The slope of the regression line showed a greater decrease in the negative relationship between ethical attitude and academic dishonesty when students perceived the surrounding climates as highly ethical. In other words, as long as students can improve their ethical attitude in a high ethical climate, opportunities for academic dishonesty can be reduced.

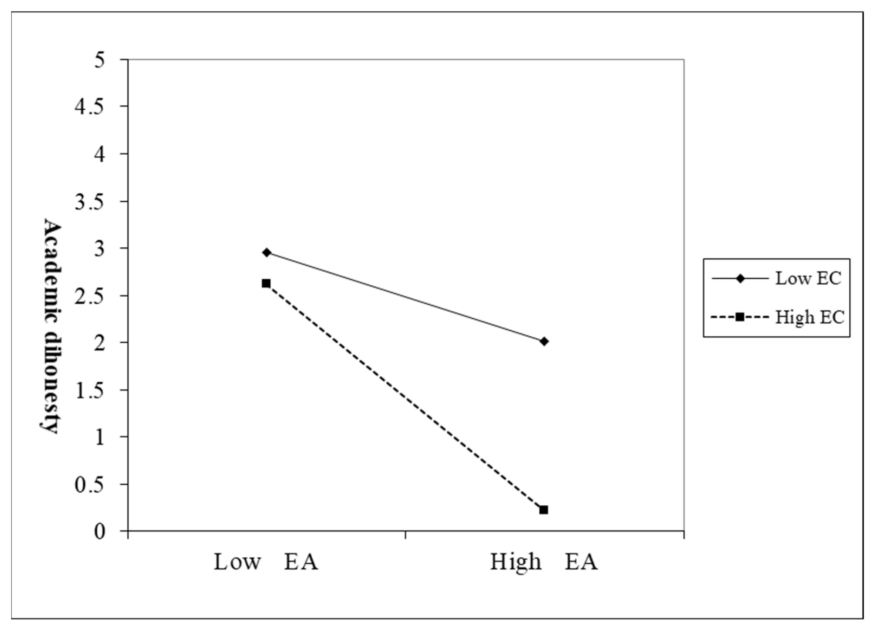

Figure 2. The moderating effect of ethical climate on the relationship between ethical attitude and academic dishonesty. Note 1: EA = ethical attitude, EC = ethical climate. Note 2: We used one standard deviation above/below the means of EA and EC to calculate the high/low values, respectively.

\section{Discussion}

This study showed the relationship between ethical attitude and academic dishonesty was significantly negative. How a person perceived an ethical climate could also strengthen their negative relationship, that is, students in a high ethical climate could less likely engage in academic dishonesty. Reflecting on the result, we discuss and suggest theoretical implications, implications for practice, limitations, as well as future research, below.

\subsection{Theoretical Implications}

Firstly, this study found that students with more positive ethical attitude were less likely to be dishonest. This is in line with the finding proposed in the TPB where Ajzen suggested that the more positive an individual's attitude was, the fewer negative behaviors obtained [20]. This could reduce the occurrence of negative behaviors. Aiming to understand and predict personal behaviors, Ajzen further suggested that attitude toward the behaviors, subjective norms, and perceived behavioral control could affect their behavioral intentions and then regulate their actual behaviors. Among these influences, the attitude was the most influential $[8,18]$. Attitude is a person's positive or negative opinion about certain behaviors. On this front, a more positive attitude may breed a stronger behavioral intention. This result agrees with prior empirical studies similar to this work. Eisenberg's 2004 study is an example. Eisenberg found that a student with higher moral standards was keen to be more honest in their academic conduct. This result was supported by a great number of scholars [25-28]. It is clear that a positive moral attitude could effectively restrain academic cheating.

Secondly, this study also found that an ethical climate could moderate the negative relationship between ethical attitude and academic dishonesty, and more specifically, that a high ethical climate would strengthen the relationship. In particular, when students per- 
ceive their surrounding climate as highly ethical, the more positive their ethical attitude is, the more effective it will be to reduce the occurrence of academic dishonesty. This allowed us to understand a step further that the interaction between the individual variable (ethical attitude) and contextual variable (ethical climate) can have an inhibiting effect on academic dishonesty [41]. The finding aligns with what [21] proposed in SCT, where he suggested that perception was mutually correlated with a person, behavior, and environment. The environment includes social norms, regulations, and encouragement from peers. These three elements were also the constituents of ethical climate in this study, namely, the class rules, and regulations for ethical attitude from the teachers, as well as the restriction and pressure from checks and balances between peers regarding academic dishonesty. This ethical climate is an effective depressant on academic dishonesty, but also a catalyst for more academic ethical behaviors. Sisti [4] found that the main cause of student cheating was that the cheater regarded it as normal because everybody was doing it. That kind of mindset created a climate to pardon their cheating behavior. This finding was also aligned with Bandura [21] on the importance of majority influence and peer pressure. Similarly, Sisti mentioned that, together with the academic ethics class rules to observe, explicit school rules and regulations on academic ethics should not ever be overlooked. Therefore, creating a positive ethical climate cannot do without the school and teacher, as well as the peer.

Furthermore, the moderator in this study, ethical climate, shares a similar characteristic with the subjective norms in Ajzen's theory, where Ajzen defined this term as the social pressure a person felt when taking certain actions. Specifically, the subjective norms were the personal perception of external pressure from loved ones or groups (such as schools, teachers, friends, peers, or others) over whether he/she could be academically dishonest. The more positive the subjective norms were, the easier the climate which forms positive intentions to behave could be created. Therefore, while students are conducting academicrelated research, subjective norms such as the requirements and regulations of academic ethics imposed by teachers, or peer pressure which creates a climate to mold students behaviors to conform to academic ethics, reinforced by the individual's positive ethical attitude, can have a positive impact on motivating students to act in accordance with academic ethics as well.

\subsection{Educational Implications}

The new curriculum guidelines emphasize a wide range of basic academic research courses such as "topical studies", "science fairs", "project-based practical course papers", or "short essays" in high schools. Students are galvanized into logical thinking, problemsolving, planning, and execution, with innovative adaptation, semiotics and expression, interpersonal relationships, and teamwork. Therefore, some suggestions based on the results are discussed below, hoping to serve as a reference for educational practices and policy development for training students' core competencies. Firstly, schools should release a set of academic ethical conducts to cultivate a positive ethical attitude in students. Teachers should set an example to integrate a positive ethical attitude into the curriculum, specifically, either teaching students to respect intellectual property rights, with academic ethical norms and regulations, or rewarding honest students generously. This will inspire students to automatically set up their own goals to accomplish basic academic research with a great sense of honor [55]. It is worth noting that this study found that the students who took the project-based practical course showed more academic dishonesty behaviors than the students who did not take the project-based practical course. To explore the reason, it may be that students show more academic dishonesty behaviors in order to successfully complete the practical course homework. It is recommended that teachers should be able to carry out academic ethics unit teaching when teaching project-based practical courses, cultivate students' positive ethical attitudes, and avoid academic dishonesty behavior. In addition, this study found that, compared with male students, female students have a more positive attitude towards ethical attitude and show less academic dishonesty. Such results 
are consistent with many studies [8,56-59]. It is recommended that teachers adopt a mixed grouping of male and female students when conducting project-based practical courses and use the team's ethical climate to reduce students' academic dishonesty behavior.

This study found that there was no difference in academic dishonesty behavior between general senior high school students and vocational senior high school students. Compared with general senior high school students, vocational senior high school students showed a more positive ethical attitude and a positive ethical climate. A high academic climate should be introduced into campuses. Teachers should encourage and support students to come to them anytime with their questions and solve them together through discussion. This could create a positive learning climate in the class, allowing students to become acquainted with the expected academic ethics from teachers and simultaneously exclude any possible influences for academic dishonesty [60]. Eventually, the academic culture could become integral and honest in the school campus [5].

\section{Limitations and Scope of Future Research}

This study was cross-sectional and the independent variable (ethical attitude) and the dependent variable (academic dishonesty) were tested at the same time, making causality between either variable hard to distinguish, and leading to the research result being too obscure to make causal implications. It is suggested, therefore, that a future study can adopt the longitudinal research method instead. Specifically, pre- and post-measurements of ethical attitude can be conducted with second-grade students during the class over a course of one year to detect any significant differences. After these students completed their third-grade "topical studies," "science fair, "project-based practical course papers or short essays", they could then be given academic dishonesty measurements to investigate the causality between their ethical attitude and academic dishonesty.

Relevant research has shown that disparities in cultural values can cause a person to have different ethical attitudes or behaviors $[16,18,61]$, so it is suggested that future research can adopt Hofstede [62] to apply various cultural values, such as individualism and collectivism, and long-term and short-term orientations, for another approach to explore whether different cultural values can also moderate the negative relationship between ethical attitude and academic dishonesty.

Finally, the objective of this study was to explore the relationship between high school students' ethical attitude and academic dishonesty and to confirm the moderating effect of ethical climate on the relationship. Under what kind of mechanism can ethical attitude affect academic dishonesty? This question is another research topic worth investigating. It is suggested that future studies can examine mediators or moderation between ethical attitude and academic dishonesty, such as to investigate academic self-efficacy, dropout intention, social support, academic performances, test anxiety, or other factors, all of which are some of the mysterious factors still waiting to be explored [6].

\section{Conclusions}

Based on the theory of planned behavior (TPB) and social cognitive theory (SCT), this study explored the relationship between ethical attitude and academic dishonesty, and confirmed the moderating effect of ethical climate on the two. This study found that ethical attitude was negatively related to academic dishonesty, and high ethical climate strengthened the negative relationship between ethical attitude and academic dishonesty. When students conduct academic-related research, teachers' academic ethics requirements and peer obedience to norms create an atmosphere to shape students' behavior to conform to academic ethics, which is reinforced by personal positive moral attitudes. Teachers should create a positive ethical climate in the classroom, so that students are familiar with the academic ethics expected by teachers, while eliminating any factors that may cause academic dishonesty. Eventually, ethical climate can become part of the campus. This study also discussed the theoretical significance, practical significance, and future research directions. It is hoped that the research results can provide a reliable reference 
for educational researchers and educational administrative agencies when planning ethicsrelated courses or high school education policies, and emphasize academic dishonesty and other related issues.

Author Contributions: Conceptualization, Y.-C.C. and F.-C.H.; data curation, H.-M.H.; formal analysis, Y.-C.C. and H.-M.H.; funding acquisition, Y.-C.C.; investigation, F.-C.H.; methodology, Y.C.C. and H.-M.H.; project administration, Y.-C.C.; resources, Y.-C.C.; software, H.-M.H.; supervision, Y.-C.C.; validation, Y.-C.C. and H.-M.H.; writing-original draft, Y.-C.C., F.-C.H. and H.-M.H.; writing-review and editing, Y.-C.C., F.-C.H. and H.-M.H. All authors have read and agreed to the published version of the manuscript.

Funding: This research was partly funded by the Ministry of Science and Technology in Taiwan, grant number MOST 110-2515-S-018-002, MOST 110-2515-S-018-003 and National Changhua University of Education, grant number New Recruits Research Project 108-01.

Institutional Review Board Statement: Before conducting the research, the researchers explained in detail the purpose and content of the research to the principals or directors of all schools, and they agreed to conduct a questionnaire survey of students in their schools.

Informed Consent Statement: Teachers in each school were informed of the purpose and content of the research and assisted in the questionnaire survey procedures. They informed the participants in advance that they could participate voluntarily and the confidentiality of the collected information.

Data Availability Statement: All participants were informed of the purpose and content of the research and voluntarily participated in the research. The data were collected and analyzed anonymously.

Conflicts of Interest: The authors declare no conflict of interest.

\section{References}

1. Finchilescu, G.; Cooper, A. Perceptions of academic dishonesty in a South African university: A Q-Methodology approach. Ethics Behav. 2018, 28, 284-301. [CrossRef]

2. Kiekkas, P.; Michalopoulos, E.; Stefanopoulos, N.; Samartzi, K.; Krania, P.; Giannikopoulou, M.; Igoumenidis, M. Reasons for academic dishonesty during examinations among nursing students: Cross-sectional survey. Nurse Educ. Today 2020, 86, 1-7. [CrossRef] [PubMed]

3. Radulovic, U.; Uys, T. Academic dishonesty and whistle-blowing in a higher education institution: A sociological analysis. Afr. J. Bus. Ethics 2019, 13, 16-41. [CrossRef]

4. Sisti, D.A. How do high school students justify internet Plagiarism? Ethics Behav. 2007, 17, 215-231. [CrossRef]

5. Thomas, A.; De Bruin, G.P. Student academic dishonesty: What do academics think and do, and what are the barriers to action? Afr. J. Bus. Ethics 2012, 6, 13-24. [CrossRef]

6. Thomas, D. Factors that explain academic dishonesty among university students in Thailand. Ethics Behav. 2017, 27, 140-154. [CrossRef]

7. Yang, S. Attitudes and behaviors related to academic dishonesty: A survey of Taiwanese graduate students. Ethics Behav. 2012, 22, 218-237. [CrossRef]

8. Zhang, Y.; Yin, H.; Zheng, L. Investigating academic dishonesty among Chinese undergraduate students: Does gender matter? Assess. Eval. High. Educ. 2018, 43, 812-826. [CrossRef]

9. Tatum, H.E.; Schwartz, B.M.; Hageman, M.C.; Koretke, S.L. College students' perceptions of and responses to academic dishonesty: An investigation of type of honor code, institution size, and student-faculty ratio. Ethics Behav. 2018, 28, 302-315. [CrossRef]

10. Chen, Y.; Chou, C. Are we on the same page? College students' and faculty's perception of student plagiarism in Taiwan. Ethics Behav. 2017, 27, 53-73. [CrossRef]

11. Li, Y. Academic staff's perspectives upon student plagiarism: A case study at a university in Hong Kong. Asia Pac. J. Educ. 2015, 35, 14-26. [CrossRef]

12. Lin, C.S.; Wen, L.M. Academic dishonesty in higher education-A nationwide study in Taiwan. High. Educ. 2007, 54, 85-97. [CrossRef]

13. Zhang, D.; Joy, M.; Cosma, G.; Boyatt, R.; Sinclair, J.; Yau, J. Source-code plagiarism in universities: A comparative study of student perspectives in China and the UK. Assess. Eval. High. Educ. 2014, 39, 743-758. [CrossRef]

14. Akbulut, Y.; Sendag, S.; Birinci, G.; Kilicer, K.; Sahin, M.C.; Odabasi, H.F. Exploring the types and reasons of Internet-triggered academic dishonesty among Turkish undergraduate students: Development of Internet-Triggered Academic Dishonesty Scale (ITADS). Comput. Educ. 2008, 51, 463-473. [CrossRef]

15. Park, C. In other (people's) words: Plagiarism by university students literature and lessons. Assess. Eval. High. Educ. 2003, 28, 471-488. [CrossRef] 
16. Karim, N.S.A.; Zamzuri, N.H.A.; Nor, Y.M. Exploring the relationship between Internet ethics in university students and the big five model of personality. Comput. Educ. 2009, 53, 86-93. [CrossRef]

17. Muñoz-García, A.; Aviles-Herrera, M. Effects of academic dishonesty on dimensions of spiritual well-being and satisfaction: A comparative study of secondary school and university students. Assess. Eval. High. Educ. 2014, 39, 349-363. [CrossRef]

18. Khazanchi, D. Unethical behavior in information system: The gender factor. J. Bus. Ethics 1995, 14, 741-749. [CrossRef]

19. Ministry of Education (MOE). The General Guidelines on Curriculum Guidelines of 12-Year Basic Education. 2014. Available online: https: / / www.naer.edu.tw / PageSyllabus?fid=52 (accessed on 1 August 2020).

20. Ajzen, I. From intention to actions: A theory of planned behavior. In Action Control: From Cognition to Behavior; Kuhl, J., Beckman, J., Eds.; Springer: Berlin, Germany; New York, NY, USA, 1985; pp. 11-39. [CrossRef]

21. Bandura, A. Organizational application of social cognitive theory. Aust. J. Manag. 1988, 13, 275-302. [CrossRef]

22. Zopiatis, A.A.; Krambia-Kapardis, M. Ethical behavior of tertiary education students in Cyprus. J. Bus. Ethics 2008, 81, 647-663. [CrossRef]

23. Ajzen, I.; Fishbein, M. Understanding Attitudes and Predicting Social Behavior; Prentice-Hall: Engelwood Cliffs, NJ, USA, 1980.

24. Eisenberg, J. To cheat or not to cheat: Effects of moral perspective and situational variables on students' attitudes. J. Moral Educ. 2004, 33, 163-178. [CrossRef]

25. Harding, T.S.; Mayhew, M.J.; Finelli, C.J.; Carpenter, D.D. The theory of planned behavior as a model of academic dishonesty in engineering and humanities Undergraduates. Ethics Behav. 2007, 17, 255-279. [CrossRef]

26. Imran, A.; Nordin, M. Predicting the underlying factors of academic dishonesty among undergraduates in public universities: A path analysis approach. J. Acad. Ethics 2013, 11, 103-120. [CrossRef]

27. Passow, H.J.; Mayhew, M.J.; Finelli, C.J.; Harding, T.S.; Carpenter, D.D. Factors influencing engineering students' decisions to cheat by type of assessment. Res. High. Educ. 2006, 47, 643-684. [CrossRef]

28. Simkin, M.G.; McLeod, A. Why do college students cheat? J. Bus. Ethics 2010, 94, 441-453. [CrossRef]

29. Chen, M.H.; Hsu, H.M.; Hsieh, C.C.; Ku, P.Y. The relationship between information ethical attitude and academic unethical behavior: The moderated effect of perceived ethical climate. In Proceedings of the Annual Meeting of the International Conference of Technological and Vocational Education for Sustainable Development, Taipei, Taiwan, 2010. (In Chinese).

30. Yu, H.; Glanzer, P.L.; Johnson, B.R. Examining the relationship between student attitude and academic cheating. Ethics Behav. 2020, 31, 475-487. [CrossRef]

31. Chiang, L.; Lee, B. Ethical attitude and behaviors regarding computer use. Ethics Behav. 2011, 21, 481-497. [CrossRef]

32. Schwepker, C.H., Jr. Ethical climate's relationship to job satisfaction, organizational commitment, and turnover intention in the salesforce. J. Bus. Res. 2001, 54, 39-52. [CrossRef]

33. Kuo, F.; Hsu, M. Development and validation of ethical computer self-efficacy measure: The case of soft lifting. J. Bus. Ethics 2001, 32, 299-315. [CrossRef]

34. LaRose, R.; Kim, J. Share, steal or buy? A social cognitive perspective of music downloading. Cyberpsychology Hum. Behav. 2007, 10, 267-277. [CrossRef]

35. Ferrell, O.C.; Gresham, L.G. A contingency framework for understanding ethical decision making in marketing. J. Mark. 1985, 49, 87-96. [CrossRef]

36. Victor, B.; Cullen, J.B. The organizational bases of ethical work climates. Adm. Sci. Q. 1988, 33, 101-125. [CrossRef]

37. Henning, M.; Malpas, P.; Manalo, E.; Ram, S.; Vijayakumar, V.; Hawken, S. Ethical learning experiences and engagement in academic dishonesty: A study of Asian and European pharmacy and medical students in New Zealand. Asia-Pac. Educ. Res. 2015, 24, 201-209. [CrossRef]

38. Schein, E. Organizational Culture and Leaders: A Dynamic View; Jossey-Bass: San Francisco, CA, USA, 1985.

39. McCabe, D.; Treviño, L. Academic dishonesty: Honor codes and other contextual influences. J. High. Educ. 1993, 64, 522-538. [CrossRef]

40. McCabe, D. Cheating: Why students do it and how we can help them stop. Am. Educ. 2001, 25, 38-43.

41. Birtch, T.A.; Chiang, F.F.T. The influence of business school's ethical climate on atudents' unethical behavior. J. Bus. Ethics 2014, 123, 283-294. [CrossRef]

42. Brislin, R.W. Translation and content analysis of oral and written material. Handb. Cross-Cult. Psychol. 1980, 2, 339-444.

43. Hair, J.F., Jr.; Black, W.C.; Babin, B.J.; Anderson, R.E.; Tatham, R.L. Multivariate Data Analysis, 7th ed.; Pearson/Prentice Hall: Upper Saddle River, NJ, USA, 2010.

44. Kline, R.B. Principles and Practice of Structural Equation Modeling, 4th ed.; Guilford Press: New York, NY, USA, 2016.

45. Hair, J.F.; Black, B.; Babin, B.; Anderson, R.E.; Tatham, R.L. Multivariate Data Analysis, 6th ed.; Macmillan: New York, NY, USA, 1992. [CrossRef]

46. Cronbach, L.J. Coefficient alpha and the internal structure of tests. Psychometrika 1951, 16, 297-335. [CrossRef]

47. Chiou, H.J. Principles and Practice of Structural Equation Modeling with LISREL/SIMPLIS, 2nd ed.; Yeh Yeh Book Gallery: Taipei, Taiwan, 2011.

48. Kutner, M.H.; Nachtsheim, C.J.; Neter, J.; Li, W. Applied Linear Statistical Models, 5th ed.; McGraw-Hill Irwin: Boston, MA, USA, 2005. [CrossRef]

49. Peng, T.K.; Kao, Y.T.; Lin, C.C. Common method variance in management research: Its nature, effects, detection, and remedies. J. Manag. 2006, 23, 77-98. (In Chinese) [CrossRef] 
50. Podsakoff, P.M.; Organ, D.W. Self-reports in organizational research: Problems and prospects. J. Manag. 1986, 12, 531-544. [CrossRef]

51. Podsakoff, P.M.; MacKenzie, S.B.; Lee, J.Y.; Podsakoff, N.P. Common method biases in behavior research: A critical review of the literature and recommended remedies. J. Appl. Psychol. 2003, 88, 879-903. [CrossRef]

52. Podsakoff, P.M.; MacKenzie, S.B.; Podsakoff, N.P. Sources of method bias in social science researchand recommendations on how to control it. Annu. Rev. Psychol. 2012, 63, 539-569. [CrossRef]

53. Li, Y.-Z. The Impact of Parental Rearing Style on Learning Engagement among Senior High School Students: A Serial Mediation Effect Model. Psychol. Dev. Educ. 2018, 34, 576-585. [CrossRef]

54. Aiken, L.S.; West, S.G. Multiple Regression: Testing and Interpreting Interactions; Sage: Thousand Oaks, CA, USA, 1991; Available online: https: / / reurl.cc/1RaapQ (accessed on 19 October 2021).

55. Schunk, D. Learning Theories: An Educational Perspective, 6th ed.; Allyn \& Bacon: Boston, MA, USA, 2012; Available online: https: / / reurl.cc/a9MXMX (accessed on 19 October 2021).

56. Gibson, C.L.; Khey, D.; Schreck, C.J. Gender, internal controls, and academic dishonesty: Investigating mediating and differential effects. J. Crim. Justice Educ. 2008, 19, 2-18. [CrossRef]

57. McCabe, D.L.; Treviño, L.K.; Butterfield, K.D. Academic integrity in honor code and non-honor code environments: A qualitative investigation. J. High. Educ. 1999, 70, 211-234. [CrossRef]

58. Tibbetts, S.G. Differences between women and men regarding decisions to commit test cheating. Res. High. Educ. 1999, 40, 323-342. [CrossRef]

59. Whitley, B.E.; Nelson, A.B.; Jones, C.J. Gender differences in cheating attitudes and classroom cheating behavior: A meta-analysis. Sex Roles 1999, 41, 657-677. [CrossRef]

60. Lemons, M.; Seaton, J. Justice in the classroom: Does fairness determine student cheating behaviors? J. Acad. Adm. High. Educ. 2011, 7, 17-24.

61. Jung, I. Ethical judgments and behaviors: Applying a multidimensional ethics scale to measuring ICT ethics of college students. Comput. Educ. 2009, 53, 940-949. [CrossRef]

62. Hofstede, G. Management scientists are human. Manag. Sci. 1994, 40, 4-13. [CrossRef] 